\title{
REACTIVITY OF ANTINUCLEAR FACTORS WITH DNA-NUCLEOPROTEINS
}

\author{
BY \\ P. J. LACHMANN \\ Department of Pathology, University of Cambridge
}

The specificity of the factors in certain pathological human sera giving rise to nuclear staining in fluorescent antibody tests has in recent years been the subject of some interest. (Krooth, Tobie, Tjio, and Goodman, 1961; Beck, 1961, 1962; Lachmann and Kunkel, 1961 ; Casals, Friou, and Teague, 1963). It has been shown that characteristic staining patterns are associated with particular antibodies. Thus, "diffuse" nuclear staining is associated with antibodies to the DNA-nucleoprotein complex, "shaggy" nuclear staining with antibodies to DNA itself, "speckled" nuclear staining with antibodies to the "phosphate extract" antigens of the nucleus, and "nucleolar" staining with antiribonucleoprotein antibodies.

Holborow and Weir (1959) reported that, if sections of testis were used as antigen, the sperm heads failed to show fluorescence, and they interpreted this and further results (see also Holborow, $1960,1963)$ as showing that histone, the protein of the DNA-nucleoprotein in somatic nuclei, was an essential part of the nuclear antigen and that the DNA-protamine found in the sperm head was unreactive.

In view of an earlier finding in this laboratory (Lachmann, 1961) that suitably pre-treated sperm heads would, however, act as substrate "nuclear" material for the L.E.-cell test, it was decided to re-investigate the specificity of nuclear staining with particular reference to the participation of nucleoprotamine in nuclear staining reactions.

\section{Antigens}

\section{Materials and Methods}

(i) Human thyroid and testis were obtained postmortem within 12 hours of death. The tissue was cut into blocks and frozen at $-196^{\circ} \mathrm{C}$. It was generally stored at this temperature until it was used.

(ii) Human spermatozoa were obtained from the Fertility Clinic. They were stored frozen at $-196^{\circ} \mathrm{C}$. in a medium containing 20 per cent. glycerol.

(iii) Desoxyribonucleic acid (DNA) was isolated from human tonsil by the method of Kirby (1959).

(iv) Salmon sperm protamine was obtained from Light and Co., Colnbrook, Bucks, and calf thymus histone from Worthington Biochemical Corporation, Freehold. New Jersey.

\section{ANTISERA}

(i) Human sera giving positive antinuclear factor (ANF) tests were obtained largely from patients at Addenbrooke's Hospital by courtesy of the physicians.

(ii) Antihuman $\gamma$-globulin serum was prepared in a rabbit by immunization with repeated courses of heataggregated human $\gamma$-globulin (Lederle, Fr.II). A predominantly $\gamma$-globulin fraction of the antiserum was conjugated with fluorescein isothiocyanate (Baltimore Biologicals) so as to give between 1 and 2 molecules of fluorescein per molecule of $\gamma$-globulin. The fluoresceinconjugated serum was used at a concentration of around $10 \mathrm{mg} . / \mathrm{ml}$. and gave a single $\gamma$-globulin line on immunoelectrophoretic analysis against human serum. It was absorbed once with $100 \mathrm{mg}$. guinea-pig liver powder per ml. conjugate.

\section{ENZYMES AND REAGENTS}

Desoxyribonuclease 1 and papain were obtained in crystalline form from Worthington Biochem:-il Corporation.

The activation buffer for papain contained $0.01 \mathrm{M}$ cysteine and $0.002 \mathrm{M} \mathrm{Na}{ }_{4}$ EDTA in 0.9 per cent. $\mathrm{NaCl}$ and was brought to a pH of $7 \cdot 1$ with $0 \cdot 15 \mathrm{M} \mathrm{Na}_{2} \mathrm{HPO}_{4}$.

"Pularin" (Evans Medical, Ltd.) was used undiluted (5000 international units/ml.) as source of heparin.

Complement-fixation test (CFT) diluent was obtained from Oxoid.

\section{Antinuclear Factor (ANF) Test}

Sections of fresh frozen tissue were cut at a thickness of $4 \mu$ on a Harris-International Cryostat. After airdrying the sections were fixed in acetone for $10 \mathrm{~min}$. at $4^{\circ} \mathrm{C}$.

Sera under test were heat-inactivated and tested, usually at a dilution of 1 in 5 , though a dilution of 1 in 2 was used for weaker sera.

The test serum was applied to the washed section for 30 minutes at room temperature. After three further washes the fluorescein-conjugated antiglobulin serum was added-again for $\mathbf{3 0} \mathrm{min}$. The sections after washing for $10 \mathrm{~min}$. were mounted in buffered glycerol.

The sections were examined in a Leitz Ortholux Microscope, using an Osram HBO200 mercury lamp as. source of ultraviolet light. 


\section{Results}

\section{Antinuclear Factor (ANF) Tests on Sections of Human Testis}

ANF tests were performed with a number of sera giving either "diffuse" or "speckled" nuclear staining (see Table I for details of sera used). Unfortunately no serum giving the "shaggy" pattern of nuclear staining was available.

The sections were examined under dark-field illumination, using both ultraviolet and visible light. The ultraviolet light is used to detect the fluorescence. The visible light allows sperm heads to be distinguished by their high refractibility.

It was found that, as reported by Holborow and Weir (1959), sperm heads, in general showed no staining with any of the sera tested.

Three explanations for this failure of the sperm heads to stain were considered:

(i) The presence of protamine (the protein of sperm heads) interferes with the ANF reaction in some non-immunological fashion; for example, its presence may quench the fluorescence.

(ii) The sperm heads are inaccessible to the antibody.

(iii) Sperm heads contain no antigenic determinants reacting with the lupus sera.

To distinguish among these possible explanations further experiments were performed.

\section{Effect of Protamine on ANF Tests}

To investigate the possibility that protamine might be affecting the ANF reaction, sections were pre-treated with 1 per cent. salmon sperm protamine for $30 \mathrm{~min}$. at room temperature and then thoroughly washed after fixation in acetone but before adding the test serum.

Protamine is a stronger base than histone and is thought to react with the native DNA-histone by displacing the histone, giving rise to a randomlycoiled form of DNA-protamine. Thus treatment

TABLE I

PATTERNS OF NUCLEAR STAINING IN A SERIES OF NINETEEN SERA

\begin{tabular}{|c|c|c|c|c|c|c|}
\hline \multirow[b]{2}{*}{ Serum } & \multirow[b]{2}{*}{ Sex } & \multirow[b]{2}{*}{ Clinical Diagnosis } & \multirow[b]{2}{*}{ L.E.-Cell Test } & \multicolumn{3}{|c|}{ Pattern and Strength of "Nuclear" Staining } \\
\hline & & & & $\begin{array}{c}\text { Untreated Section } \\
\text { (Thyroid) }\end{array}$ & $\begin{array}{l}\text { Protamine-Treated } \\
\text { Section (Thyroid }\end{array}$ & $\begin{array}{l}\text { Papain-Treated } \\
\text { Sperm Smear }\end{array}$ \\
\hline 1 & $\mathbf{M}$ & Normal & $\mathbf{0}$ & $\mathbf{0}$ & 0 & 0 \\
\hline 2 & $\mathbf{F}$ & Systemic L.E. & +++ & +++ Diffuse & $(+)$ & +++ \\
\hline 3 & $\mathbf{M}$ & Systemic L.E. & +++ & +++ Diffuse & + Inhomogeneous & $(+)$ \\
\hline 4 & $\mathbf{F}$ & Systemic L.E. & ++ & +++ Diffuse & 0 & + \\
\hline 5 & $\mathbf{F}$ & Systemic L.E. & ++ & +++ Diffuse & + Inhomogeneous & ++ \\
\hline 6 & $\mathbf{F}$ & Systemic L.E. & ++ & +++ Diffuse & + Inhomogeneous & $+t+$ \\
\hline 7 & $\mathbf{F}$ & Systemic L.E. & ++ & +++ Diffuse & + Inhomogeneous & +++ \\
\hline 8 & $\mathbf{F}$ & Systemic L.E. & ++ & +++ Diffuse & 0 & ++ \\
\hline 9 & $\mathbf{F}$ & Systemic L.E. & $(+)$ & +++ Diffuse & ++ Inhomogeneous & + \\
\hline 10 & $\mathbf{F}$ & ? Systemic L.E. & $\mathbf{0}$ & + Diffuse & 0 & 0 \\
\hline 11 & $\mathbf{F}$ & "Lupoid hepatitis" & 0 & +++ Diffuse & 0 & + \\
\hline 12 & $\mathbf{M}$ & Rheumatoid Arthritis; ? Systemic L.E. & $\mathbf{0}$ & +++ Diffuse & $(+)$ & + \\
\hline 13 & $\mathbf{F}$ & Sjögren's syndrome & $\mathbf{0}$ & ++ Diffuse & 0 & 0 \\
\hline 14 & $\mathbf{F}$ & Sjögren's syndrome & $\mathbf{0}$ & ++ Speckled & ++ Inhomogeneous & $\mathbf{0}$ \\
\hline 15 & $\mathbf{F}$ & "Collagen disease" & $\mathbf{0}$ & ++ Speckled & ++ Inhomogeneous & $\mathbf{0}$ \\
\hline 16 & $\mathbf{F}$ & Cirrhosis & $\mathbf{0}$ & +++ Diffuse & $(+)$ & + \\
\hline 17 & $\mathbf{M}$ & Carcinoma kidney & 0 & ++ Diffuse & 0 & 0 \\
\hline 18 & $\mathbf{F}$ & Myasthenia gravis & 0 & +++ Diffuse & + Inhomogeneous & $(+)$ \\
\hline 19 & $\mathbf{M}$ & Myasthenia gravis & $(+)$ & +++ Diffuse & 0 & + \\
\hline
\end{tabular}

Notes: 1 . Staining reactions are read on an arbitrary scale +++ Very strong.

++ Strong.

+ Moderate

2. All sera were tested undiluted on the sperm smears and diluted 1:5 on the tissue section.

3. The sperm smears give weak background staining with the fluor itself. The readings recorded are for staining above this level.

4. Where staining was weak $(+)$ the morphology was difficult to make out clearly and is not included.

5. The L.E.-cell tests were performed by the indirect technique using $0.5 \mathrm{ml}$. serum. 
with protamine alters the structure and configuration of the DNA-protein and leaves protamine in the section even after washing. The results obtained (Table I) made it apparent that:

(1) "Diffuse" nuclear staining tended to be abolished or much reduced.

(2) "Speckled" nuclear staining was retained, although its morphology was somewhat altered. This is referred to as "inhomogeneous" in Table I. With occasional sera rather similar inhomogeneous staining could be seen in the protamine-treated sections, whereas it was masked by diffuse staining in the control sections. This provides an immunofluorescent technique for showing up the antibodies giving this type of staining in the presence of the antibodies giving diffuse staining.

These results show that the presence of protamine alone does not inhibit ANF tests, since it does not abolish the "phosphate extract" staining. Moreover, it shows that most antibodies reacting with the native nucleohistone will not react with the "random nucleoprotamine" formed in this way.

Protamine treatment was also found to be without effect on the staining of thyroid colloid by the serum of a patient with Hashimoto's disease.

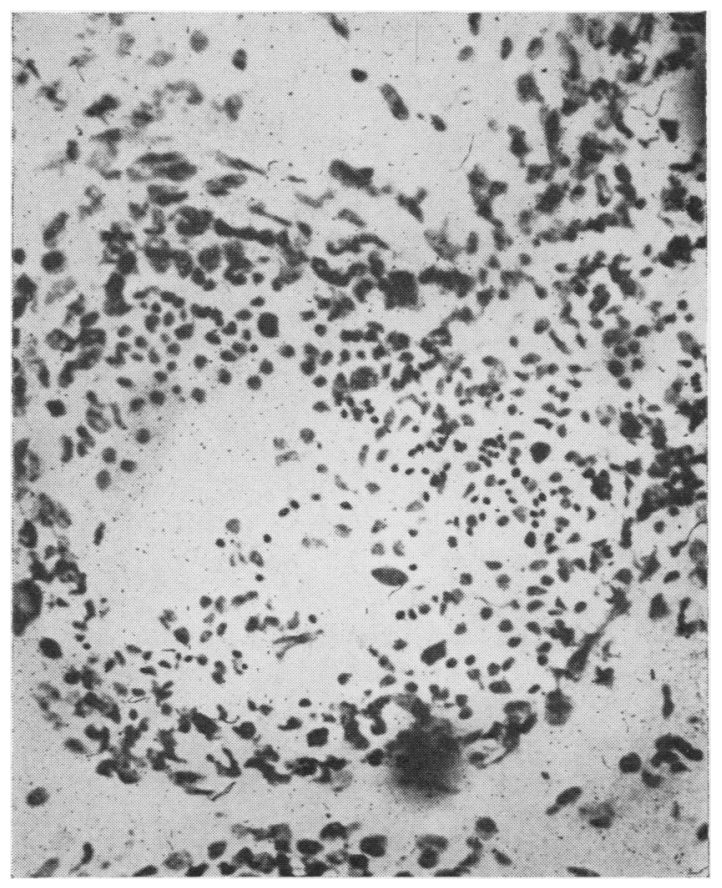

Fig. 1.-Section of human testis stained by Feulgen technique.

\section{Effect of Desoxyribonuclease (DNA-ase) on Sections of Human Testis}

The enzyme, desoxyribonuclease 1, rapidly hydrolyses DNA even when it is in combination with protein. Histochemically this hydrolysis can readily be detected as the tissue becomes Feulgen-negative. The molecular weight of the enzyme is around 60,000 , i.e. it is a good deal smaller than a $7 \mathrm{~S}$ $\gamma$-globulin antibody molecule with a molecular weight of around 150,000.

The sections were cut and fixed in acetone in the usual way. The sections were then treated at $37^{\circ} \mathrm{C}$. for $30 \mathrm{~min}$. with 2 drops of a solution of DNA-ase at a concentration of $200 \mu \mathrm{g}$. $/ \mathrm{ml}$. in CFT diluent containing 0.25 per cent. crystalline bovine plasma albumin. This concentration of enzyme is at least 100 times the minimum effective strength. Control sections were treated with diluent only. After this incubation the sections were washed free of enzyme in saline containing $\mathrm{M} / 100$ EDTA (which stops enzyme activity by chelating magnesium ions). This treatment was followed by fixation in 10 per cent. formol saline and Feulgen staining.

Figs 1 and 2 show the appearance in the control sections and these treated with DNA-ase respectively.

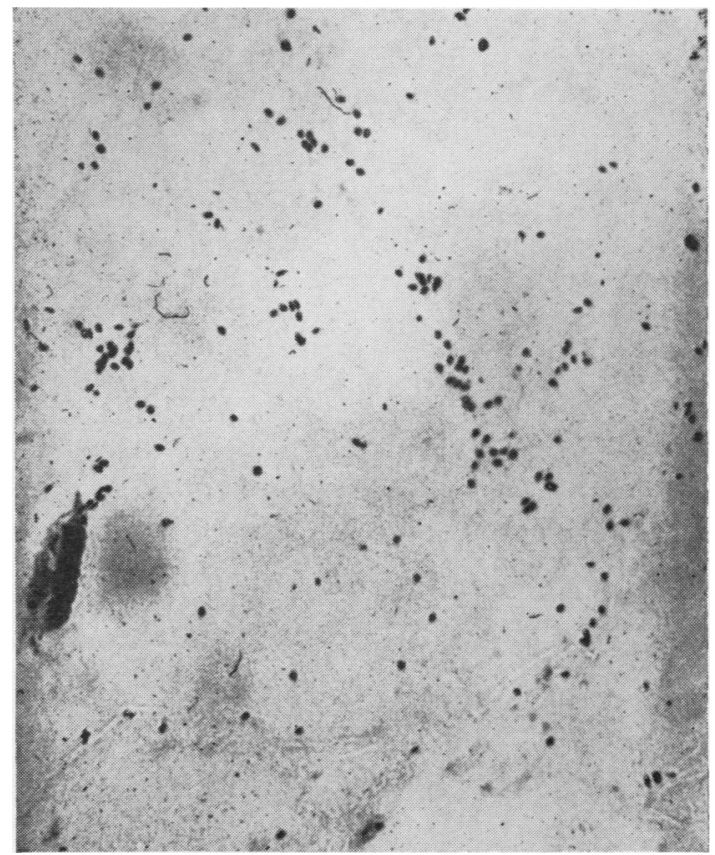

Fig. 2.-Section of DNA-ase-treated human testis stained by Feulgen technique. 
It can be seen that the sperm heads have retained their Feulgen staining after DNA-ase treatment, whereas the other nuclei have lost staining. The failure of the enzyme to hydrolyse the spermatozoal DNA and thereby to make the sperm heads Feulgennegative can be regarded as evidence of their impermeability to a molecule considerably smaller than 7S antibody.

This finding supports the hypothesis that sperm heads are inaccessible to antinuclear antibodies, even in cut sections.

Similar assessment of accessibility to DNA-ase by Feulgen-staining of sections before and after treatment with this enzyme were carried out on sections pre-treated with papain and heparin as described in later sections. Table II summarizes the results.

\section{Methods of Increasing the Accessibility of Sperm Head Antigens to Antibody}

(a) Influence of the Conditions of Storage of the Frozen Tissue.-Blocks of fresh frozen tissue were generally stored at $-196^{\circ} \mathrm{C}$. Under these conditions the reactivity of the tissues was not observed to vary over a period of several months. If frozen tissue was stored at $-25^{\circ} \mathrm{C}$., changes in reactivity were observed. These were manifested mainly in an increase in the "background staining" of the tissue. However, in the case of the testis under study in these experiments, it was also observed that after a few weeks at $-25^{\circ} \mathrm{C}$. a small proportion of the sperm heads did show staining in the ANF test with a strong lupus serum.

(b) Effect of Papain.-Mild treatment with papain was found previously to be the best treatment for rendering sperm reactive in L.E.-cell tests. Papain treatment of sections of testis was therefore attempted. Crystalline papain was suspended in the activating buffer at a concentration of $1 \mathrm{mg}$. in $3 \mathrm{ml}$. This suspension was then diluted $1 / 10$ in saline before use.

Sections for enzyme treatment were acetone-fixed in the usual way. It was found that treatment with the enzyme for more than about $15 \mathrm{~min}$. at room temperature caused the sections to break apart. Sections treated with enzyme for $15 \mathrm{~min}$. were then washed and used in the usual way. Feulgenstained sections showed both nuclei and sperm heads giving positive staining. If the papain-treated sections were then treated with DNA-ase, only an occasional sperm head was still Feulgen-positive (Table II).

In the ANF test, papain treatment did not diminish "diffuse" nuclear staining, although "speckled" nuclear staining was generally abolished. The effect on the sperm heads was variable. The majority still failed to stain and retained their characteristic refractility when viewed by visible light. However, a minority did show staining and these had lost this refractility. The presence of the surrounding nuclear staining makes these staining spermatozoa difficult to demonstrate. Thus, under the conditions used, the papain treatment had made most of the sperm heads accessible to DNA-ase, while only a smaller proportion seemed to have become accessible also to the larger antibody molecule.

Similar experiments were performed on smears of spermatozoa rather than sections of testis to avoid interference by other nuclear fluorescence. The spermatozoa were treated with enzyme, washed, and resuspended in a drop of normal rabbit serum. Smears were made, quickly air-dried, and fixed in acetone for $10 \mathrm{~min}$. at $4^{\circ} \mathrm{C}$. These were then used as substrate for the ANF test.

It was observed that, whereas smears of untreated spermatozoa gave little staining with any of the sera tested, the papain-treated smears gave strong staining of the vast majority of sperm heads, with most sera giving rise to diffuse nuclear staining (Table II).

However, of sera giving strong diffuse nuclear staining, some gave stronger staining of sperm heads than others.

Figs 3 and 4 (opposite) show the ANF reactions on papain-treated sperm given by two typical L.E. sera at a dilution of $1 / 5$. Both sera were strongly L.E.-cell positive and both give strong diffuse

TABLE II

FEULGEN STAINING OF TESTIS SECTIONS

\begin{tabular}{|c|c|c|c|c|}
\hline \multirow{2}{*}{ Pre-treatment of Section } & \multicolumn{2}{|c|}{ Feulgen Staining } & \multicolumn{2}{|c|}{ Feulgen Staining after DNA-ase } \\
\hline & Nuclei & Sperm heads & Nuclei & Sperm heads \\
\hline None & Strong (used as reference) & Strong (used as reference) & Abolished & Unaffected \\
\hline Papain & Unaffected & Unaffected & Abolished & $\begin{array}{l}\text { Abolished in the great majority } \\
\text { Occasional sperm heads still } \\
\text { stain }\end{array}$ \\
\hline Heparin & Much weakened & Unaffected & Abolished & Abolished \\
\hline
\end{tabular}




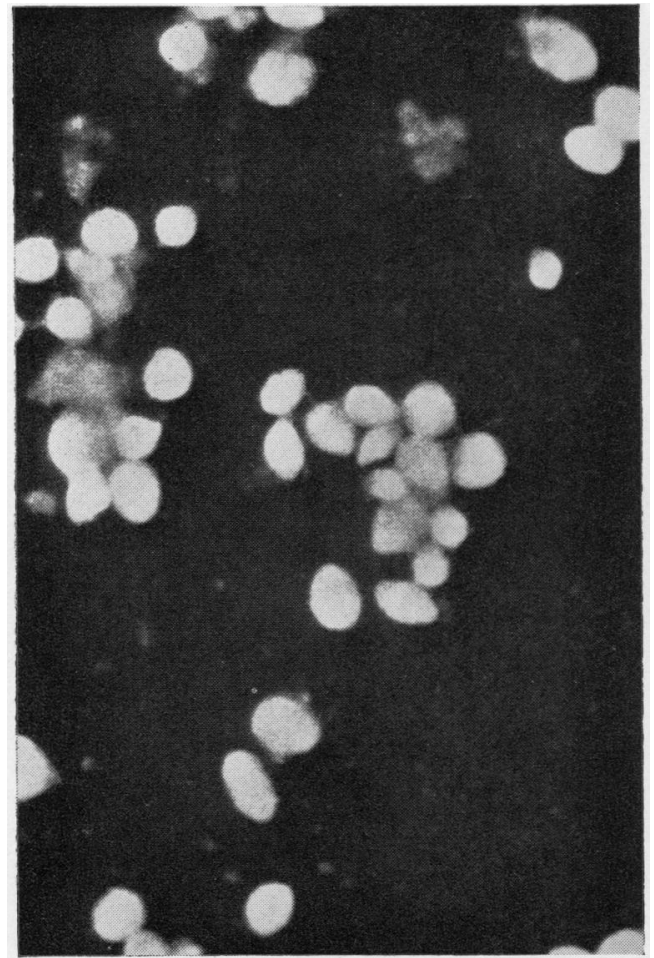

Fig. 3.

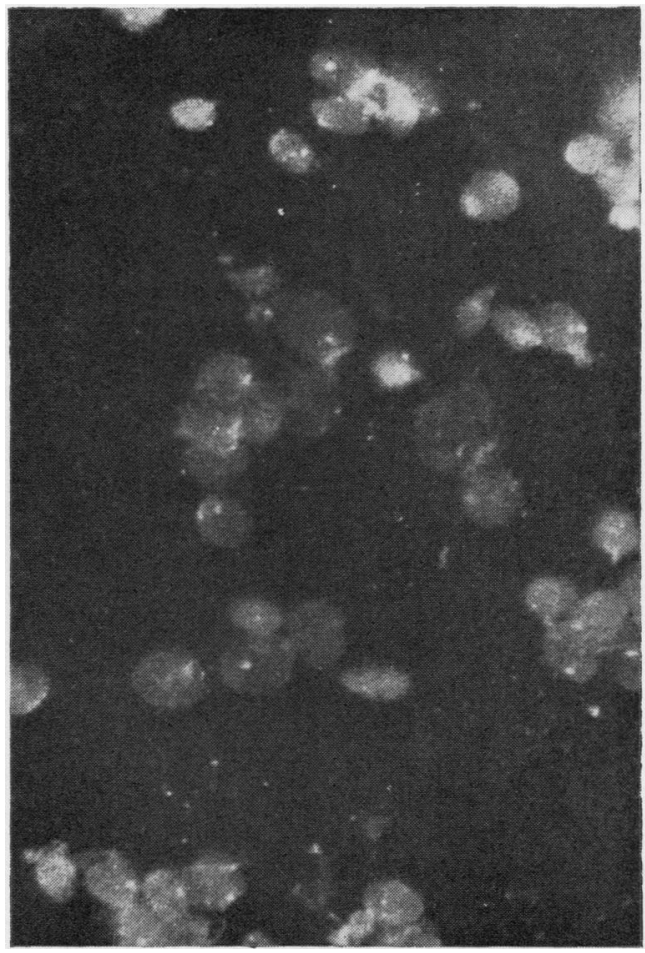

Fig. 4.

Figs 3 to 5.-ANF tests on smears of papain-treated human sperm.

(3) Using Serum 2, strongly positive.

(4) Using Serum 4, moderately positive.

(5) Using normal human serum, negative.

nuclear staining in the conventional ANF test. However, one serum (2) gave much stronger sperm head staining than the other (4).

Fig. 5 shows a normal serum control. Two sera giving speckled nuclear staining failed to show staining with these smears. It is, however, not improbable that any phosphate extract antigen would have been washed out in the course of the enzyme treatment, so that it cannot be concluded that sperm heads contain no phosphate extract antigens.

In these smears nearly all the sperm heads are accessible to antibody and morphologically swollen, compared with the small number which underwent these changes in the sections. It is not clear whether this difference reflects genuine differences in the spermatozoa or is due to technical causes. Therefore it still appeared desirable to devise a method to produce sperm head staining in sections, preferably in the absence of nuclear staining. For this purpose sequential treatments were tried with

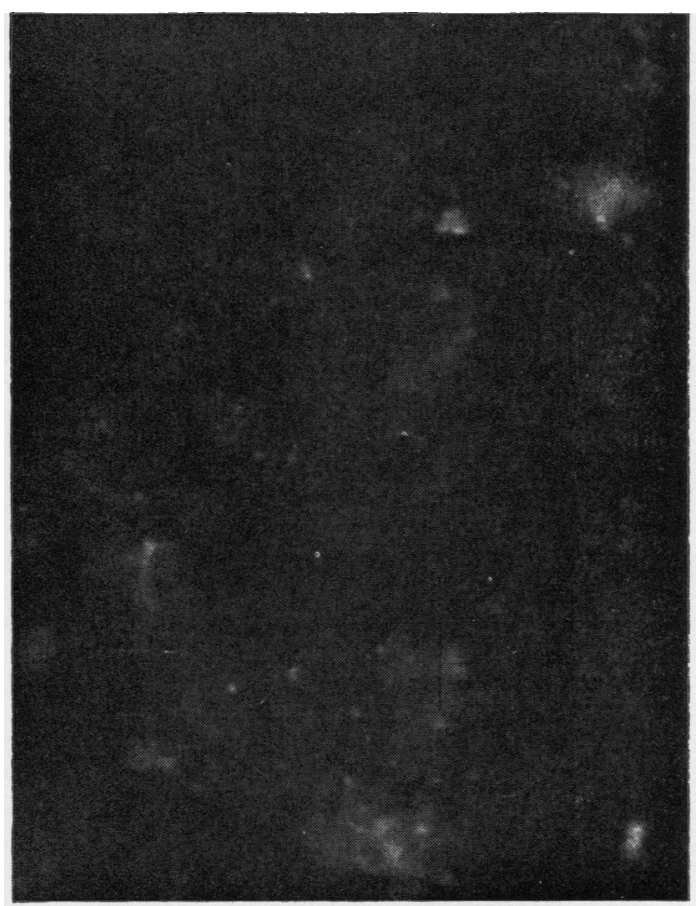

Fig. 5. 
protamine and papain, and DNA-ase and papainthe first to block nuclear staining, the second to render the sperm accessible - but the results in both cases were unsatisfactory. The sections became very difficult to handle and very liable to considerable background staining.

(c) Effect of Heparin on the ANF Test.-Heparin is a strong polyacid and is believed to react with the native DNA-histone, by replacing (to some extent) the DNA and producing a "randomly-coiled" heparin-histone complex. Its action is, thus, in some respects analogous to that of protamine. Feulgen staining of heparin-treated testis showed a reduction in the Feulgen staining of the nuclei while the sperm heads stained normally. If the heparintreated sections were then treated with DNA-ase, all Feulgen staining was abolished (Table II).

It would appear that, while heparin does not exert its DNA-replacing effect on spermatozoal nucleoprotamine, which is very much more difficult to break up chemically than nucleohistone (Vendrely, Knobloch, and Vendrely, 1957), it does have some effect on the permeability of the sperm membrane. It had been previously observed that heparintreated spermatozoa would act as substrate in the L.E.-cell test.

In the ANF test heparin-treated sections were rather disappointing showing considerable background staining. However, diffuse nuclear staining with typical lupus sera was generally abolished. Some speckled nuclear staining was retained. It was difficult to wash away the displaced DNA which tended to precipitate with the $\gamma$-globulin in any serum and to give a fluorescent precipitate lying on the section. This effect could be reduced by working at $\mathrm{pH} 8$.

In contrast to the nuclei, the sperm heads did now show staining (Fig. 6), with the L.E. sera giving strong staining of sperm smears.

These results suggest that histone alone is not normally the essential antigenic constituent of the DNA-histone. The heparin-treated sections contained a heparin-histone complex but did not stain with most of the sera tested. The results show also that, after suitable pre-treatment, sperm heads in the testis may show staining with sera that give staining of sperm smears.

(d) Absorption of Sera with Reconstituted Nucleoproteins.-To test the conclusion that most antinuclear factor-like the L.E.-cell factor itselfreacts with native nucleoprotein rather than with its constituents, positive sera were absorbed as follows:

To $0.5 \mathrm{ml}$. serum was added $1 \mathrm{mg}$. DNA dissolved in distilled water. After $30 \mathrm{~min}$. either $1 \mathrm{mg}$ calf thymus

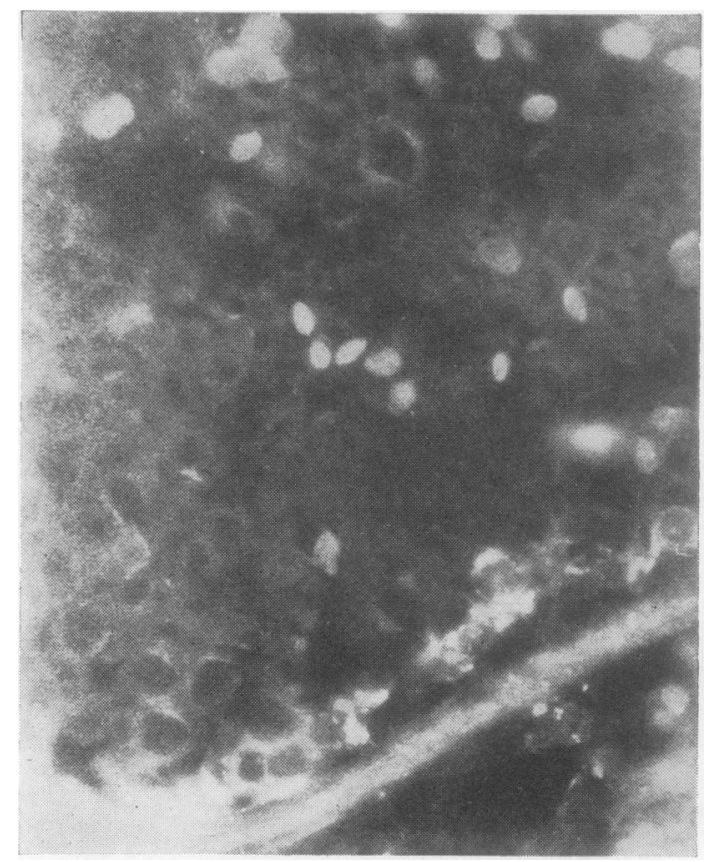

Fig. 6.-ANF test on heparin-treated human testis, showing sperm head staining.

histone, or $1 \mathrm{mg}$. salmon sperm protamine was added. In all cases a precipitate formed at once. Incubation was continued for a further $30 \mathrm{~min}$. and the precipitate was then removed by centrifugation.

Absorption with neither the reconstituted nucleohistone nor the reconstituted nucleoprotamine weakened significantly either "diffuse" staining (in three sera) or "speckled" staining (in one serum).

\section{Discussion}

The finding of Holborow and Weir (1959) that sperm heads do not show staining in the ANF test has in general been confirmed. These workers interpreted their results as showing that the histone moiety of the DNA-protein complex in somatic nuclei determines the reactivity with antibody in the ANF test. Since sperm heads do not contain histone they do not stain.

The experiments described above, however, would suggest that the explanation for the failure of sperm heads to stain is due-with some sera at any ratenot to their carrying none of the relevant antigenic determinants but rather to their inaccessibility to the antibody. Thus it has been found that in sections the sperm heads are not accessible to bovine pancreatic DNA-ase which, with a molecular weight of 
around 60,000 is considerably smaller than $7 \mathrm{~S}$ antibody. Furthermore, treatment with papain which makes sperm heads reactive in L.E.-cell tests-also renders a proportion of them stainable in the ANF test. This can be more readily demonstrated with smears of spermatozoa than with sections of testis, the latter tending to fall apart after much enzyme treatment.

A further explanation of the failure to stain - that protamine might interfere with the fluorescent staining - was considered, but was discarded after it was shown that "speckled" nuclear staining (associated with antibodies to antigens which are not part of the DNA-protein) was not abolished by pre-treatment of the sections with protamine. However, it was found that such pre-treatment did abolish most of the "diffuse" nuclear staining (associated with antibodies to antigens composing the DNA-protein). Protamine-treated sections can therefore be used as antigen to test sera for the antibodies giving "speckled" nuclear staining in the presence of the antibodies giving "diffuse" nuclear staining which in untreated sections tends to mask them (Lachmann and Kunkel, 1961).

The findings that "denaturation" of the nucleoprotein complex either with protamine or with heparin abolishes most of the whole nuclear staining, suggests that most antinucleoprotein antibodies react, not with the isolated chemical components, but with determinants peculiar to the native complex. In this respect the native DNA-protein would then resemble other native protein antigens, where the fragments resulting from denaturation carry between them only a proportion of the antigenic determinants of the native molecule. The failure to abolish staining by absorbing sera with reconstituted nucleoproteins reinforces this conclusion. Rather similal findings have previously been found to apply in the case of the L.E.-cell factor itself. However, there is no doubt that antibodies to isolated DNA and isolated histone do occur, and it has recently been shown that the former-presumably when present in high concentration-are associated with a "shaggy" pattern of nuclear staining.

These antibodies to the isolated components would seem generally to be present, when at all, as minor components compared to the antibodies to the native complex, and not to play a dominant part in producing a positive ANF test. However, the fact that such antibodies occur is some evidence that the DNA-nucleoprotein is itself the antigenic material, rather than a carrier for other substances (as it is, for example, for the "phosphate extract") which could be the true antigens involved in the diffuse patterns of nuclear staining. This possibility, though unlikely, is difficult to exclude entirely.

The native nucleoprotamine of sperm seems to share some, though not all, of the determinants in native nucleohistone which give rise to "diffuse" nuclear staining.

\section{Summary}

The antibodies giving rise to diffuse nuclear staining in the ANF test have been found to show specificity largely for the native nucleoprotein complex rather than for its constituent parts. The native nucleoprotamine of sperm heads shares some of these determinants with the nucleohistone of somatic nuclei.

The failure of sperm heads to stain in the ANF test with a number of positive sera has been found to be due to their inaccessibility to the antibody rather than to the lack of appropriate antigenic determinants or to any non-specific interference by sperm head protamine.

Sections pre-treated with protamine have been found to provide a test system for detecting inhomogeneous staining by sera which will with untreated tissue give diffuse staining.

This work was carried out during the tenure of an Empire Rheumatism Council Research Fellowship and was supported in part by U.S. Public Health Service Grant No. A.5782 from the National Institute of Arthritis and Metabolic Disease. The author is grateful to these organizations and to Dr. R. R. A. Coombs, in whose laboratory the work was performed. He is also much indebted to Miss Rosemary Liske for technical assistance; to Mr. W. A. Mowlam for performing the Feulgen staining, and to Mr. B. W. Gurner for help with the photography.

\section{REFERENCES}

Beck, J. S. (1961). Lancet, 1, 1203. (1962). Ibid., 1, 241.

Casals, S. P., Friou, G. J., and Teague, P. O. (1963). J. Lab. clin. Med., 62, 625

Holborow, E. J. (1960). Proc. roy. Soc. Med., 53, 625.

- (1963). In "Clinical Aspects of Immunology", ed. P. G. H. Gell, and R. R. A. Coombs, p. 681. Blackwell, Oxford.

_ and Weir D. M. (1959). Lancet, 1, 809.

Kirby, K. S. (1959). Biochem J., 71, 27P.

Krooth, R. S., Tobie, J. E., Tjio, J. H., and Goodman, H. C. (1961). Science, 134, 284.

Lachmann, P. J. (1961). Immunology, 4, 153.

- and Kunkel, H. G. (1961). Lancet, $2,436$.

Vendrely, R., Knobloch, A., and Vendrely, C. (1957). Exp. Cell Res., 13, Suppl. 4, p. 279. 
La réactivité des facteurs antinucléaires avec les nucléoprotéines de l'ADN

\section{RÉSUMÉ}

On a trouvé que les anticorps donnant lieu à une coloration nucléaire diffuse dans le test de l'ANF (facteur antinucléaire) sont, en sa majorité, spécifiques du complexe nucléoprotéique natif plutôt que de ses constituants. La nucléoprotamine native des têtes spermatiques partage certains de ces déterminants avec le nucléohistone des noyaux somatiques.

Le fait que les têtes spermatiques ne se colorent pas dans le test de l'ANF avec certains sérums positifs est dû à leur inaccessibilité à l'anticorps et non pas à l'absence des déterminants antigéniques appropriés ou à une intervention non-spécifique de la protamine de la tête spermatique.

Des coupes traitées préalablement par la protamine offrent un moyen pour déceler une coloration peu homogène par des sérums qui, avec des tissus non traités, donnent une coloration diffuse.
La reactividad de los factores antinucleares con las nucleoproteinas del ADN

Sumario

Se demuestra que los anticuerpos que dan lugar a una coloración nuclear difusa en el test de ANF (factor antinuclear) son en su mayoría específicos del complejo nucleopı otéico nativo más bien que de sus partes constituyentes. La nucleoprotamina nativa de las cabezas espermáticas participa de ciertas de estas determinantes con la nucleohistona de los núcleos somáticos.

El hecho de que las cabezas espermáticas no se coloran en el test de ANF con ciertos sueros positivos se debe a su inaccesibilidad al anticuerpo y no a la ausencia de las determinantes antigénicas apropriadas o a una intervención non-específica de la protamina de la cabeza espermática.

Cortes previamente tratados con protamina ofrecen un sistema de tests para evidenciar una coloración poco homogénea por sueros que, con tejidos sin tratar, dan una coloración difusa. 